\title{
WATCHING SELF FROM A DISTANCE: THE WHYS OF WATCHING SINETRONS AMONG MALAY-JAVANESE WOMEN IN MALAYSIA
}

\author{
Lily El Ferawati Rofil \\ lily.ef@uny.ac.id \\ Department of Communication Sciences Yogyakarta State University
}

\begin{abstract}
This article discusses the cognitive reasoning behind the love for watching sinetronexpressed by Malay-Javanese women in Malaysia. The Malay-Javanese women in this context refer to female members of Javanese communities within Malay society. Malaysians of Javanese descent are constitutionally considered as ethnic component of Malay racial group due to similarities in cultural customs and religion of Islam. However, they retain some semblance of Javanese cultural heritage including speaking the language in their everyday life. In the context of Malay-Javanese women under this study, it is identified that sinetrons have become the main source of their cultural consumption from television. Sinetrons aresoap opera-like television productions from Indonesia-the country where their ancestors were originated from. The results from ethnographic fieldwork in Kampung Papitusulem of Selangor show how these women incline to watching sinetrons to a certain level, primarily due to three main reasons. First, the dialogues in the television productions fit their language preference. Second, they can find representations of their cultural identity in the images of sinetrons. Third, they watch the imported television program from Indonesia simply for the identification ofsense of belonging. It is argued that viewing sinetrons for these women represents watching self from a distance, which is central discussion in cultural and media studies.
\end{abstract}

\begin{abstract}
Abstrak
Artikel ini membicarakan pemikiran kognitif di sebalik kecintaan menonton sinetron dalam kalangan wanita Melayu-Jawa di Malaysia. Wanita Melayu-Jawa dalam konteks ini merujuk pada warga perempuan dari komunitas Jawa dalam masyarakat Melayu. Menurut Konstitusi Malaysia, warga negara Malaysia keturunan Jawa dianggap sebagai komponen etnik dari kelompok bangsa Melayu karena memiliki kesamaan adat budaya dan keyakinan sebagai Muslim. Pada hakikatnya, mereka masih mengekalkan beberapa komponen warisan budaya Jawa seperti penggunaan Bahasa Jawa dalam keseharian mereka. Dalam konteks wanita Melayu-Jawa yang dibahas dalam artikel ini, diketahui bahwa sinetron telah menjadi salah satu sumber budaya termediakan oleh televisi yang mengeratkan pertalian dengan asal usul mereka. Sinetron merupakan produksi televisi yang tergolong genre opera sabun berasal dari Indonesia-negara yang menjadi tanah kelahiran pendahulu wanita tersebut. Hasil dari kerja lapangan etnografi, di Kampung Papitusulem, Selongor, menunjukan bagaimana wanita-wanita ini menyukai sinetron pada tahap tertentu karena tiga alasan utama. Pertama, dialog yang digunakan dalam sinetron sesuai dengan preferensi mereka. Kedua, mereka dapat menemukan identifikasi identitas budaya mereka dalam representasi sinetron. Ketiga, mereka menonton program televisi yang diimport dari Indonesia sebagi ekspresi rasa memiliki terhadap Indonesia. Ini menunjukkan bahwa menonton sinetron bagi wanita
\end{abstract}


Melayu-Jawa mempunyai makna seperti melihat identitas diri dari kejauhan, dan ini merupakan diskusi sentral dalam kajian media dan budaya.

Keywords: Television, Audience Ethnography, Cultural Identity

\section{INTRODUCTION}

The discussion in this article is centred around the prime reasons of watching sinetrons among a group of Malay-Javanese women in Malaysia. The Malay Javanese women in this study refer to female members of a Javanese community in Sabak Bernam, a district in the state of Selangor with a large population of Javanese descendants. To be exact, the study was done in Kampung Parit Tujuh Baroh or is better known by the locals as KampungPapitusulem which stands for Parit Pitu Sungai Leman. The word pitu is the Javanese translation of the word seven in English, while Sungai Leman is the name of the mukim - the administrative village of the residency. According to the kampung headman, Javanese descendants make up 90 percent of the population in the kampung (Rofil, 2016). Hence, the study chose this kampung as the site of the fieldwork.

A typical kampung in Malaysia usually refers to a political stronghold of Malay population (Shamsul, 1997), which the author previously conceives of as a homogenous society of Malay “pure” race. From theauthor's initial observation of the Malay communities in Kuala Lumpur and in the media, the Malays tend to have strong awareness of their conventional customs and overwhelming compliance with Islamic rules. Even more significant is the fact that all Malays were born Muslim. In contrast, in a slightly plural Indonesia, Javanese entity does not affiliate with a particular religion and its traditional customs are partially adapted to Islam. Clifford Geertz's The Religion of Java (1976) described that in the process of embracing Islam, Javanese attempted to preserve their animist belief which they transformed into abangan religion, the variant of Islam in Java. Therefore, theinitial assumption about the Malaysian Javanese was that they withdrew from any connection to Javanese culture and completely integrated into Malay society. However, the reality is otherwise.

The Malaysian Javanese are among the ethnic groups of Indonesian origin that constitute today's Malay population, which seem to be referred to as a "branch" of the Malay race (Milner, 2002). Although in Indonesia, Malay and Javanese are two distinct ethnic groups, the Malaysian constitutions view both societies as one under the same racial category. As the Malaysian definition of race is determined by "customs and religion" (Milner, 2002: 68), the Javanese are considered as Malay because they are culturally and religiously similar to the Malays. In addition, this conception of race construes "Malayness" as an "inclusive culture" because Islam as the key marker of identity enables similar Indonesian ethnic groups to be anointed as one racial entity (Reid, 2001). According to the Article 153 of the Constitution of Malaysia, Malays refer to those who "profess the religion of Islam, habitually speak the Malay language, and conform to Malay customs" (Yeoh, 2006: 2).

It can be said that the Malays may include any Muslim Malaysian citizens who habitually speak Malay and follow Malay adat (see Andaya and Andaya, 2001; Kahn, 2006; Vickers, 2004). The Malays of Javanese descendants are no exception. The existence of Javanese descendants in Malaysian society is apparent and their identity construction is important to note. Their presence in the country's contemporary political and social scenes depicts that they are not a part of migrantsocietyof Indonesiaanymoreand thus the literature about them should be shifted from historical to cultural perspectives. This is due to the fact that identity is no longer a product of colonial discourses, but rather an attachment of everyday culture in which television is present. And this study proves that watching television narratives from 
ancestors' homeland can build Javanese diaspora's self-narratives of shared cultural identity which represents their interpretive communities.

\section{Television and Interpretive Communities}

Television audience are social human beings who share social and cultural norms with their fellow communions in their communities. Theyintentionally and unintentionally monitor the social and cultural practices of the people around them through reflexivity (Giddens, 1991, 1984). In the contexts of television consumption, members of audience are most likely to interpret the cultural texts in the same way as the other members of their society do (Fish, 1980). In other words, Fish (1980) further argues that audience interpret media narratives as they read cultural text similar to their "interpretive communities." This notion of interpretive communities refers to a way of sharing the same "ways of reading" as community members have the same perspective towards cultural texts which concern their community (Fish, 1980: 14).

The conceptual framework of interpretive community has been applied in studies on the relationships between media and culture. This is because television provides a set of power relations that are mediated through cultural symbols(Lindlof, 2002). Television messages as encoded texts (Hall, 1980) deliver hegemonic or ideological elements of "culture" which are broadcast within cultural and national boundaries and beyond (Abu-Lughod, 1997). Therefore, cultural production through television also speaks for the notion of interpretive communities. Lila Abu-Lughod (1997: 128) argues that television serves a practical function for "writing against the grain" because it enables the producers to construe people in distant places as part of the same cultural worlds they inhabit. Local producers usually use local cultural values to construct the representation of community that audience can identify with (Tinic, 2006). On the other hand, audience can reflect cultural representations depicted on television based on their personal experiences in everyday lives even they live far from the centre of the production (Abu-Lughod, 1997; Mankekar, 2002, 1993; Tuchman, 1994). This confirms that television content producers and viewers from a same culture are framed in the same cultural boundaries of interpretive communities.

A member of community shares communal milieusin terms of values, traditions, and customswithothercommunity members within the same cultural bounds. However, such communal experiences may differ from one community from another Fish (1980). Previous studies show that audience do not only search for cultural proximity but also the gap, and the alternative subjects between their culture and representations on television. La Pastina's (2004) ethnography on the reception of telenovelas in rural Brazil notes that rural audience view urban culture as shown in television programme at a distance through which they interpret the messages based on social and political contexts in their understanding. Similarly, urban viewers who are more open to modern ideas also interpret cultural texts within a particular social and cultural context. Timothy Scrase's (2002) ethnography in a middle-class society of West Bengal, India, reveals that cultural texts are negotiated in the account of "othering". The viewers in the middle-class West Bengali households identify the gap between the televisual culture and their everyday culture by which they use such labels as "non-Western", "nonBengali", and "non-traditional" (Scrase, 2002: 331). The account of "othering" appears to be a common interpretation of television in relation to cultural identities (see also Mankekar, 2002).

In general, audience identify themselves with "cultureof location" in their consumption of television. They employ selfregulation in determining the cultural texts that they desire to observe when dealing with cultural representations from different locations. For instance, Chinese teens from 
immigrant families in the United States of America exhibit two modes of viewing cultural content on television (Louie, 2006). The youth place themselves as Chinese diaspora and locate family and ethnic values when they tune to Chinese movies and dramas, but in contrast, they reflect on their American identity and seek pleasure in their consumption of American programmes (Louie, 2006). Similarly, the diaspora girls in a Mexican American community of San Antonio in Texas also locate different culture of locations through which they identify with Mexican, Hispanic, and American identities in their reception of telenovelas (Mayer, 2003).

Basically, self and social experiences influence the ways people read and interpret cultural texts on television. For example, Adriaens (2014)learnsfrom her visual ethnography of television that Turkish diaspora girls in Belgium choosegender and class as crucial determinants in the teens' cultural identity. Precisely, teenagers learn about gender and class through social interactions in their family and peer groupsto reflect values on their interpretation of cultural texts (Adriaens, 2014; McMillin and Fisherkeller, 2009; Roussou; 2002). As Nayia Roussou (2002) points out, youth in a mixed society such as Greek-Cypriot community, actively identify traditional family values through linguistic elements of culture in the perception of their cultural identity as depicted on television.

Despite the universality in the way of watching television, different age groups make sense of television-mediated culture in different ways (Harwood, 1997). Jake Harwood points out that "viewing television programmes that feature characters who come from the same age group makes audience experience elevated age identity and self-esteem" (Harwood: 1997: 210). In this way, it is assumed that the adults in this study may have different determinants of cultural identities in their interpretation of culture in watching television.

In the context of this study, how cultural or ethnic identities are represented on television and how audience negotiate such representations to construct theirs are the main concerns of the discussion. Precisely, this article presents the ways Malay-Javanese women interpret their cultural identity in the depictions of everyday culture screened on television dramas, especially Indonesia's sinetrons. Gail Coover (2001: 414) notes that "race is portrayed in the media in two ways: through the content of a message or program, and through the race representation of sources included in a program or story." This shows that ethnic identities are represented in contextual and visual/textual elements of the televisual narratives. Coover (2001) discovers that members of audience are most likely to identify with the presentation of the members of their racial groups. It shows that recognizing characters from the same cultural or ethnic group is a crucial identification of cultural identity. Apart from the characters, dialogues can also mediate between the audience and their culture (Shetty, 2008). Shetty's (2008) study on a community broadcasting in a Southern Indian ethnic group reveals that traditional Tulu language which is used in a programme called Pattangacan assist the viewers to construct their views pertaining to caste, class, and gender identities.

\section{METHOD}

\section{From the Fieldwork}

The findings presented in this article represent only a part of the empirical data from ethnographic fieldwork at the KampungPapitusulem. As stated in the beginning of this article, the village was selected as the site of the fieldwork because it was dubbed as a Javanese village which has over 90 percent Javanese descendants in the population.It is located approximately 120 kilometres from the capital Kuala Lumpur.

The fieldwork employed two basic ethnographic techniques of data collection: in-depth interviews and participant observations(Fetterman, 2010;Gobo, 2008). It took place between April 2013 and September 2014 through two series of prolonged stays. 
As many as 20 women from the same social network were recruited as the participants of the interviews. They appeared to be the second and third generations of Javanese descendants who still speak Javanese fluently on a daily basis.

The interviews contained a set of unstructured questions about the informants'daily television diet and their interpretation of television contents from the programs that they watched such as news, dramas, reality shows and so forth. They were also asked to talk about their everyday activities including social and political experiences. The outcomes of the interviews led to series ofobservation of theinformants' daily lives. The researcher (later mentioned as ethnographer) even cowatched television with some of them with their consent. Apart from the co-watching, the observation included involvement in the informants' activities in community gatherings such as rewang (shared labour to prepare a traditional ceremony), religious congregations, and in their involvement in the 2013 Malaysia's General Election.

The data from the interviews and participant observation were thematically analysed used NVivo1osoftware. Thethematic analysis allowed the data to be presented into several themes (Guest MacQueen and Namey, 2011). Using inductive way of data coding, it turned out that this study discovered four main themed findings. The findings presented in this article represents only a half of one of the themes which talks about why Javanese women in this study prefer watching imported sinetrons from Indonesia to local dramas. Basically, they watched sinetrons primarily because they have their own preference of language, culture of location, and sense of belonging.

\section{RESULT AND DISCUSSION}

\section{Preferred Language: “... because I like the language."}

Member of audience can self-regulate themselves to locate images of identity on television which represents their gender, community, social class, ethnicity and nation (Barker, 1999; Thompson, 2002). When they watch television, they both pay attention to visual representations of their world and monitor visual materials which symbolises cultural norms and values of their own community (Fish, 1980). It is argued that they make sense of their identity through watching television by identifying symbolic circumstances of life to construct substantive ideas about their existence within their community. In the process of meaning making, they derive self-reflexivity (Barker, 1997; Giddens, 1991) as well as collective commonalities (Fiske, 2011; Price, 1995) from the television representations which subsequently signify their identifications with a particular society.

Television productions such as dramas or soap operas certainly provide narratives which concern cultural features of society that audience can identify with (Turner, 2005). However, to make sense of such narratives, the audience need to have certain knowledge and experiences which link their narrative of self to the mediated narratives (Barker, 1997; Castelló, 2009; Livingstone, 1998). Sonia Livingstone (1998) notes that members of audience employ selectiveviewing in which they interpret semantic representations of their world using prior knowledge about their social world, communities, and events. Such semantic representations appear to be in the form of cultural elements such as folklore, music, gastronomy, dress codes, and rituals which audience can identify with (Castelló, 2009). In the same manner, the MalayJavanese women in this study can identify the representations of their culture in television by recognising linguistic accent, traditional dress codes, and culturally religious values (Rofil, 2016: 126).

In the interviews, the informants were asked about their favourite television drama series. As expected, most of them expressed that they preferred watching sinetrons to watching Malay dramas primarily due to the production's linguistic elements.

I like watching cerita Indonesia
(Indonesian dramas). ${ }^{1}$ The story is 
entertaining. It is so different from cerita Melayu(Malay dramas). I don't know. It seems like there is something missing (in the Malay dramas). They should adopt cerita $P$ Ramlee ( $P$ Ramlee's movies). The current (Malay) dramas are nothing comparable to P Ramlee's. $P$ Ramlee's are not boring and they are similar to Indonesian dramas, especially the dialogues (Mbah Ton, ${ }^{2} 70$, personal communication, 31 March 2014).

MbahTon, whose both parentsoriginated from Kebumen, a regency in Central Java, claims that she watches Indonesian dramas on an everyday basis. She also likes P Ramlee's movies that broadcast on television. Comparing between Indonesian dramas and local (Malay) dramas, she conceives that Indonesian dramas and P Ramlee's movies are more entertaining due to the style of the language.

Another informant also expressed the same opinion. It is the linguistic element that makes this informant tune to a sinetron whenever she switches television on. She finds that the dialogues used by the casts in sinetrons are entertaining.

In one afternoon, I watch this onecerita Indonesia. It airs two episodes in a row. This girl (the female lead) likes to mock a guy who hits on her. In the class, she does everything but studying. She also likes to scold her classmates. If she gets angry, she shouts at everybody. Anyway, the way she speaks is so entertaining. Why have I never heard you speaking like that? (Mbah Uki, 67, personal communication, 29 May 2014).

During a co-watching session, Mbah Uki talked about an Indonesian drama series, Heart Series, which was aired on a local subscription-based channel Astro Ria.While watching, she narrated the ethnographer what the series was about. The drama which is adapted from an Indonesian movie entitled Heart tells a story about high school life of middle class teenagers in Indonesia. Referring to the main female character, she asked if the ethnographer spoke like she and the rest of the casts in the drama did. Apparently, the ethnographer sometimes stayed in Mbah Uki's house and never talked in fully Bahasa Indonesia, which made her wonder. The ethnographer preferred switching between Bahasa Malaysia and Javanese depending on whose she was talking to. Particularly, Mbah Uki was more convenient with using Javanese in her daily life.

Language becomes an important aspect for the female Javanese descendants to identify with when locating cultural representations in the consumption of television. As Malaysian citizens, they are observed to use the national language, Bahasa Malaysia, which is de facto the language of the Malays. However, they admire the accent of Bahasa Indonesia because it sounds formal and pleasing.

Apart from the moral stories, Indonesian dramas are better in terms of the acting and the dialogues. The dialogues sound like formal speech. I like to listen to it (Ibu Par, 47, personal communication, 28 May 2014).

I like the dialogues (in Indonesian dramas). They sound like formal speech. I like it. I watch one drama which cast Indonesian and Malaysian actors. They use both languages. I sound like them when I speak Bahasa Malaysia. Some people identify me as an Indonesian. I say, indeed $I$ am an Indonesian descendant (Mbah Min, 63, personal communication, 20 May 2014).

Knowing that the ethnographer was an Indonesian, most of the informants and other village residents tried to impersonate the characters in Indonesian dramas when they spoke to her. Ibu Par and Mbah Min wereamong them. Sometimes they tried to utter some Indonesian words to the ethnographer whenever encountered in a gathering. They speak fluent Bahasa Malaysia with a strong Javanese accent as they speak Javanese practically every day. In the interview, both of themadmitted that people often had mistaken them as an Indonesian due to their strong Javanese accent. 
Interestingly, both particular informants regard the dialogues in Indonesian sinetrons as formal speech which contributes a factor for their inclination to watch the television genre. As the ethnographer observes, most of the dialogues in sinetronsuse colloquial expressions. It is understood that they perceived the dialogues as formal most likely due to the pronunciation which equals the style of Bahasa Malaysia used in songs and poetry. Malaysian singers and poets articulate lyrics in the same way Indonesians pronounce Indonesian words. Similarly, the style of the dialogues in P Ramlee's movies sounds the same as Indonesian.

\section{Preferred Culture of Location: “...Cerita Indonesia, Cerita Kampung.”}

Apart from the language, the MalayJavanese women in this study prefer watchingsinetrons because they can reflect their everyday experiences on "the location of culture" in the television productions. They can derive a sense of belonging to the localised culture and the cultural locality depicted in the Indonesian dramas. As the members of a rural community who live a rustic life, they can relate to the cultural representations of the ordinary life in the sinetrons. They perceive that sinetrons represent a kampung (village) life, while Malay dramas symbolise an urban modernity.

A couple of years ago, (the narrative of) Bawang Merah Bawang Putih was so relevant to our kampung life. The local dramas were not. The drama was "cerita kampung" (which) touched upon the kampung people (who) still love to wear kain batik (patterned sarong). The local dramas seem to be "cerita bandar", only depict rich families who run a corporate company. It is impossible for us to relate to such narrative. Is that (drama) about us? In real life, the Malays do not live that life(Ibu Nan, 43, personal communication, 3 June 2014).

For me, the local dramas are not interesting at all. The story always concerns a life within a corporate company, in high buildings. I don't like such stories. I better watch Indonesian drama. It is interesting because the soundtrack is reminiscent of zikir (Islamic chants). Most Indonesian dramas use an Islamic song (as the soundtrack) that mentions the Allah's names. I have never heard such song is played in the local dramas. Only recently $I$ heard it (in a local drama) on TV AlHijrah, but the drama seems to copy an Indonesian drama (Mbah Rin, 58, interview, 29 April 2014).

Ibu Nan could differentiate between cerita kampung (rural-centred dramas) and cerita bandar (urban-centred dramas). For her, an Indonesian sinetron such as Bawang Merah Bawang Putih,provided the cultural representations of a kampung life that she could relate to, while Malay dramas focused on symbolic life or urban communities, which was irrelevant to her situated culture. The dichotomy of cerita kampung and cerita bandar indeed exists in the consumption of television dramas among Malay women. Thompson (2000) suggests that the Malay kampung women in his study pleasantly enjoy the narratives of cerita kampung and cerita bandar as part of the process of transforming into the modern world. In contrast, Javanese rural women in this study would rather retain a reflexive identification with suburban life in Indonesian dramas.

The drama Bawang Merah Bawang Putih that was broadcast on the local channel $\mathrm{TV}_{3}$ in 2006 adopts a Malay archipelago's popular Cinderella-like fairy tale with the same title. The title literally means Shallot and Garlic, but it illustrates the tale of the good which is symbolised as putih (white), will always overcome the evil-signified as merah (red). As agents who have their own narratives of experience to understand media messages (Tuchman, 1994), audience from different locations of culture can interpret the images presented in a television drama in many ways. Due to the traditional image of the character, this particular informant conceived that the drama represents a kampung life, relating it to her experience of wearing such attire when she was young. 
Both Ibu Nan and Mbah Rin locate the materials of their culture within the representation of rural/suburban life in Indonesian dramas. They use self-experiences to regulate their engagement in the dramas. With such cultural disposition, they are capable of locating the cultural/religious elements in the drama to reflect on. This illustrates how they negotiate the cultural texts in the media to construct their identity.

\section{Preferred Sense of Belonging: “...because I am an Indonesian."}

Apart from the language and the location of culture, some of the respondents watch television programmes based on their personal identification with the country where the content originates from. They engaged in watching sinetronsbecause they regarded themselves as an Indonesian. They plainly claimed the Indonesian descent because their ancestors originated from the Indonesian island of Java. Similarly, they like viewing local programmes due to their nationality and current domicile in Malaysia.

I don't know why I like cerita Indonesia, (it is) probably because my father originated from there (Mbah Ton, 70, personal communication, 31 March 2014).

News is number one. I watch news about the government because I am a Malaysian citizen. ... I am an Indonesian; of course, I like cerita Indonesia (Mbah Ngat, 62, personal communication, 31 March 2014).

It is actually similar (between Indonesian and Malaysian programmes). I watch Indonesian programmes because I am an Indonesian. I watch local programmes because I live here (Mbah Sar, 66, personal communication, 4 April 2014).

Mbah Ton, Mbah Ngat, andMbah Sar belong to the second generation of Javanese descendants who live in the kampung. Their parents were Javanese migrants who moved to Malaysia before the country gained its independence. They certainly have first-hand experience and information about how life in
Java was back in those days. In addition, Mbah Ton and Mbah Ngat ever visited their parents' hometown in Java many years ago. Mbah Sar, on the other hand, spent her childhood with her father who strongly followed Javanese customs. Even though she never visited Java, she inherited Javanese cultural values and customs right from his father. Hence, she and the other second-generation descendants of Javanese who participated in this study had strong sense of belonging and identification with Javanese and Indonesian culture.

\section{Conclusion}

Conclusively, this article talks about the reasons of their love for watching Indonesian sinetrons. First, they identify the language as fascinating and closer to what they practice in their everyday lives. Second, they can locate the culture of location from sinetrons which they perceive as similar to their everyday culture. Third, they manifest sense of belonging to their entire subjectivity as Indonesian descendants in which they derive self-identification with the country of origin of the television productions.

Hall (1996) contends that identity is a continual production of human practices and values that takes place within representation. Clearly, the Malay-Javanese women in this study locate their preferred cultural identity by identifying the linguistic, cultural, and personal aspects in Indonesian and Malaysian television productions. They activate their cognitive functioning by recalling their self-experience with traditional life to situate such elements of culture and subsequently self-regulate their interpretation of the culture to determine the essential aspects of identity. It is argued that these female members of Javanese diaspora exercise self-regulatory engagement in Indonesian cultural productions that represent their situated cultural lives as rural Malay women of Javanese descent. Their love for watching sinetrons serves as one of efforts for construction of cultural identity. In this way, their consumption of the television genre represents a way of watching self from 
a distance.

\section{Notes}

1. The interviews were conducted in Javanese and Bahasa Malaysia depending on the preference of the informants. When asked about which television they watch frequently, they mentioned cerita Indonesia which referred to sinetrons that were aired in local television.

2. The names of the informants mentioned in this article are pseudonym with original Javanese honorifics such as Mbah and $I b u$. Mbah is a Javanese word to refer and old person while $I b u$ is a title given to a married middle-aged woman.

\section{REFERENCES}

Abu-Lughod, L. (1997). The interpretation of culture(s) after television. Representations, (59), 109-134.

Adriaens, F. (2014). Diaspora girls doing identities: Creating ideal television programmes and narratives of the self. European Journal of Cultural Studies, $17(2), 101-117$.

Andaya, B. W., \& Andaya, L. Y. (2001). A history of Malaysia (2nd ed.). Hampshire: Palgrave.

Barker, C. (1999). Television, globalization and cultural identities. Berkshire: Open University Press.

Castelló, E. (2009). The nation as political stage: A theoretical approach to television fiction and national identity. International Communication Gazette 71(4), 303-322.

Coover, G. E. (2001). Television and social identity: Race representation as "White" accommodation. Journal of Broadcasting E Electronic Media, 45(3), 413-431.

Fetterman, D. M. (2010). Ethnography: Stepby-step. Thousand Oaks: Sage

Fish, S. (1980). Is there a text in this class? The authority of interpretive communities. Cambridge: Harvard University Press.

Fiske, J. (2011). Reading the popular (2nd ed.). Abingdon: Routledge

Geertz, C. (1976). The religion of Java. Chicago: University of Chicago Press.

Giddens, A. (1984). The constitution of society: Outline of the theory of structuration. Berkeley: University of California Press.

Giddens, A. (1991). Modernity and selfidentity: Self and society in the late modern age. Stanford: Stanford University Press.

Gobo, G. (2008). Doing ethnography. London: Sage. 
Guest, G., MacQueen, K. M, and Namey, E. E. (2012) Applied thematic analysis. Thousand Oaks: Sage.

Hall, S. (1996). "Who needs 'identity'?" In S. Hall \& P. Du Gay (Eds.), Questions of cultural identity (pp. 1-17). London: Sage.

Harwood, J. (1997). Viewing age: Lifespan identity and television viewing choices. Journal of Broadcasting \& Electronic Media, 41(2), 203-213.

Kahn, J. S. (2006). Other Malays: Nationalism and cosmopolitanism in the modern Malay world. Singapore: NUS Press.

La Pastina A. C. (2004). Telenovela reception in rural Brazil: Gendered readings and sexual mores. Critical Studies in Media Communication, 21(2), 162-181, doi: 10.1080/07393180410001688056

Lindlof, T. R. (2002). Interpretive community: An approach to media and religion. Journal of Media and Religion, 1(1), 6174. doi: 10.1207/s15328415jmr0101_7

Livingstone, S. (1998). Making sense of television: The psychology of audience interpretation (2nd ed.). London: Routledge.

Louie, J. K. Y. (2006). Television, ethnic identity, and race: The views of Chinese Youth from immigrant families (Doctoral thesis). Available from ProQuest Dissertations \& Theses. (UMI No. 3221638)

Mankekar, P. (1993). National texts and gendered lives: An ethnography of television viewers in a North Indian City. American Ethnologist, 20(3), 543563.

Mankekar, P. (2002). Epic contests: Television and religious identity in India. In F. D. Ginsburg, L. Abu-Lughod, \& B. Larkin (Eds.), Media worlds: Anthropology on new terrain (pp. 134-151). Berkeley: University of California Press.

McMillin, D., \& Fisherkeller, J. (2009). Local identities in globalized regions: teens, everyday life, and television. Popular Communication, 7(4), 237-251. 10.1080/15405700903221343

Milner, A. (2002). The invention of politics in colonial Malaya: Contesting nationalism and the expansion of the public sphere. Cambridge: Cambridge University Press.

Price, M. E. (1995). Television, the public sphere, and national identity. Oxford: Oxford University Press.

Reid, A. (2001). Understanding Melayu (Malay) as a source of diverse modern identities. Journal of Southeast Asian Studies, 32(3), 295-313. doi: $10.2307 / 20072348$

Rofil, L. E. F. (2016). Television consumption and the construction of hybrid identity among female descendants in Malaysia (Doctoral thesis). University of Malaya, Kuala Lumpur, Malaysia.

Roussou, N. (2002). Research note: Television, cultural identity and youth lifestyles in Cyprus: Secure moorings in a shifting world?. European Journal of Communication, 17(3), 355-367.

Scrase, T. J. (2002). Television, the middle classes and the transformation of cultural identities in West Bengal, India. International Communication Gazette, 64(4), 323-343.

Shamsul A. B. (1997). The economic dimension of Malay nationalism: The socio historical roots of the new economic policy and its contemporary implications. The Developing Economies, 35(3), 240-261.

Shetty, M. L. (2008). Television and the construction of Tulu identity in South India (Doctoral thesis). Retrieved from ProQuest Dissertations and Theses. (3341959)

Thompson, E. C. (2000). In K.L.-andkampung: Urbanism in rural Malaysia (Doctoral thesis). Available from ProQuest Dissertations \& Theses. (UMI No. 9983558) 
Thompson, K. (2002). Border crossings and diasporic identities: Media use and leisure practices of an ethnic minority. Qualitative Sociology 25(3), 409-418.

Tinic, S. (2006). Global vistas and local reflections negotiating place and identity in Vancouver television. Television \& New Media, 7(2), 154-183.

Tuchman, G. (1994). Realism and romance: The study of media effects. In M. R. Levy \& M. Gurevitch (Eds.), Defining media studies: Reflections on the future of the field (pp. 278-283). New York: Oxford University Press.

Tuchman, G. (1994). Realism and romance: The study of media effects. In M. R. Levy \& M. Gurevitch (Eds.), Defining media studies: Reflections on the future of the field (pp. 278-283). New York: Oxford University Press.

Turner, G. (2005). Cultural identity, soap narrative, and reality TV. Television $\mathcal{E}$ New Media, 6(4), 415-422. doi: 10.1177/1527476405279864

Vickers, A. (2004). 'Malay identity': Modernity, invented tradition and forms of knowledge. In T. P. Barnard (Ed.), Contesting Malayness: Malay Identity across boundaries (pp. 25-55). Singapore: Singapore University Press.

Yeoh, C. R. (2006). Malaysia, truly Asia? Religious pluralism in Malaysia. The Pluralism Project-Research Report, 42. Retrieved from http://www.pluralism. org/reports/view/42. 
296 